\title{
Old Testament stories and Christian ethics: Some perspectives from the narrative of Judah and Tamar
}

\author{
Meyer, Esias \\ University of Pretoria \\ sias.meyer@up.ac.za \\ Pietersen, Leonore \\ University of Pretoria \\ lpiete@gmail.com
}

\begin{abstract}
The relationship between Old Testament narrative and Christian ethics is challenging. When it comes to finding ethical guideline Old Testament narratives are unresponsive. This is particularly the case with a narrative such as Genesis 38. Biblical scholars have written extensively on how the text can be interpreted. In this article we look at the various ways scholars in Biblical criticism have tried to make sense of the text. We show that narratives can function as a platform for dialogue to mirror the intricacies of life. We do not attempt to resolve the tension between the story and ethics, but rather aim to consider biblical criticism as a tool which stimulates ethical debate.
\end{abstract}

Keywords

Judah, Tamar, Old Testament stories, Christian ethics

\section{Introduction}

In John Barton's recent book Ethics in Ancient Israel he reminds us that 'Old Testament narrative is well known to be sometimes reticent in drawing moral conclusions from the stories it presents' (2014:171). This unresponsiveness of Old Testament narratives has been a problem for biblical critics and Christian ethicists alike and the story of Judah and Tamar in Genesis 38 is a case in point, although one wonders whether this story is really so 'reticent'. At least towards the end of the story in verse 26 we have Judah saying that 'She is more in the right than I' (NRSV), which sounds more like an invitation to an audience to engage in moral reflection 
than the conclusion to a story being reluctant to do that. Yet as we will see later, what Judah actually means is not that clear. What is clear, though, is that biblical critics have indeed responded to the lure of the story, if not exactly by looking for ethical guidelines in the story.

\section{Genesis 38}

Many commentaries and articles have engaged with the text, with the years after 2009 and especially 2012 being particularly productive with at least eight articles published. ${ }^{1}$ In most of these studies the classic questions of biblical criticism are addressed; these are often categorised as either diachronic or synchronic questions. An example of the former is Amit (2009:285), who dates the text to the Persian period and thinks that the story 'served as an anti-isolationist polemical position on the crucial issue of marriage with foreign women.'2 We could thus describe the text as 'antixenophobic.' According to another examole, that of Leuchter (2013:223), the text is from the end of the eight century during 'Hezekiah's urbanization project.' For Leuchter (2013:225) Tamar is a symbol of 'sacred hinterland fertility' and an indication 'that Judah is restored to righteousness and that the survival of his progeny is secured.' Leuchter thinks that the story is aimed at the royal administration of the time and the objective is to get that administration to end 'its assault on the institutions of the hinterland.' The story becomes a protest against urbanisation. Thus both Amit and Leuchter have more general historical-critical questions in mind when they read the text. They argue for a specific historical context, where the story has a specific socio-political message. Neither of them is really interested in contemporary ethical debates, although it should be clear that

1 See, for instance, Amit (2009), Abasili (2011a), Abasili (2011b), Kruschwitz (2012), Claassens (2012), Kim (2012), Wünch (2012) and Leuchter (2013).

2 The weakness in Amit's argument is that he thinks that Tamar was Canaanite, which is never explicitly mentioned in the text. Amit (2009:275) argues that Judah is 'completely surrounded by Canaanites' and adds that Tamar 'lived near Timnath in the Judean lowland - as local inhabitants who were mostly Canaanites during the period in question.' We are not so sure. Why does the text not say this explicitly as it does with Judah's wife (v. 2)? See also the criticism of Ebach (2007:125). Although in support of Amit's argument, one could add that the picture painted within the narrative world is one in which the family of Jacob lives amongst Canaanites. 
both offer readings which might actually be stimulating for current ethical discourses, especially Amit's reading about being open to strangers.

Scholars such as Abasili (2011a), Kim (2012), Kruschwitz (2012) and Wünch (2012) have more synchronic questions in mind, either focusing on Genesis 38 as such, or how this story is related to the rest of the Joseph narrative in which it is imbedded. Abasili (2011a:286-288) argues that the main theme of the narrative is 'the search for offspring and progeny.' Kim (2012:558559) thinks that the story of Tamar is characterised by a 'bucket-shaped structure' and has three important themes namely 'family building', 'shame' and 'deceit.' Kruschwitz (2012:409-410) looks for similarities between the Tamar story and the Joseph narrative and finds them 'in plot pattern and ironic tone.' For Wünch (2012:804) the purpose of Genesis 38 is to show why Judah became the leader of the brothers. The incident with Tamar transformed Judah into somebody worthy of leadership. The story is told here to explain the role played by Judah in the latter part of the Joseph narrative (Gen. 48 and 49). These four scholars offer readings which are ahistorical and they are more interested in how the story as such functions, either on its own (Abasili and Kim) or within the broader narrative (Kruschwitz and Wünch). None of them is interested in contemporary ethical debates.

Abasili (2011b:556) published another article, in which he writes (somewhat unusually) from the perspective of a childless Igbo woman. The article makes use of 'African contextual hermeneutics' and he shows (as in Abasili 2011a) that, from the perspective of a childless Igbo woman, the story is about progeny. Although this reading is much more context conscious, it is not overtly interested in ethics. The point we want to make is that of the eight articles published by biblical critics since 2009, seven are not interested in contemporary ethics. The only exception in this regard is Claassens (2012).

For Claassens (2012:661) the stories of Tamar and Ruth (which she also engages with) are stories about human dignity and the human tendency to struggle against and resist dehumanisation. Claassens touches on many of the issues already presented above. Like Amit, Claassens (2012:672) emphasises the role of the foreigner, especially in the Ruth narrative, although in Genesis 38 Tamar is considered an outsider by Claassens 
and thus plays a similar role. ${ }^{3}$ Furthermore, for Claassens (2012:672) Judah learns to protect vulnerable people in society, which explains why he later protects Benjamin in the Joseph narrative, which makes her approach broadly similar to Wünch's. Yet the main thrust of her article is to argue that biblical narratives could play a role in discourses on both 'moral complexities' and the 'particular contexts' of women who resist dehumanisation. In this regard she draws on the earlier work of Barton and a hence short engagement with his contribution is needed now.

\section{Implicit virtue in Old Testament narratives?}

Over the years Barton's engagement with ethics and the Old Testament has shown that two models are especially important in dealing with ethics in the Old Testament. These are natural morality and the requirement of obedience to God. ${ }^{4}$ Yet he has often attempted to engage with virtue ethics, although it seems rather reluctantly. Thus he warned (in Barton 2003:67) that although the Old Testament can be used for moral formation, this is not what the Bible is primarily about:

Hebrew culture differs from Greek on precisely this issue: the

Hebrew Old Testament does not operate with any idea that one can

grow in virtue but sees virtue as something one either has or lacks.

Moral formation or growing in virtue is one of the features often associated with virtue ethics (Barton 2003:65) and Barton thinks that it is absent from the Hebrew Old Testament, although as we will argue later, the development of Judah in Genesis 38 (as pointed out by Claassens and Wünch) might be a different story. Barton argues that in the Old Testament moral goodness is about taking moral decisions that are in line with prevailing divine law (Barton 2003:69). Still Barton (2003:71) wants to talk about 'implicit virtue' and now he uses the work of Martha Nussbaum, where the tragedy of characters in narrative is analysed. This is done to see what can be learned from characters in 'these stories in order to learn about the difficulties and

3 This part of her argument is a bit unclear. How is Tamar an outsider? She is part of Judah's family and thus an insider. Yet in the light of the discussion in the previous footnote Claassens might not be totally wrong.

4 See especially his latest, namely Barton (2014: 64-157) and earlier Barton (2003:45-54) and (2002:77-97). 
merits of living a moral life or the problems of failing to do so' (Barton 2003:72). In this sense the reader becomes aware of the complications of life and the moral decisions humans have to make amidst these complications.

Furthermore, Barton (2003:73) asks whether even if there is 'little or no virtue ethics in the Bible, may not the Bible be used constructively by those who are trying to achieve what virtue ethics puts forward as the great aim of human life: the achievement of stable and good moral character?' It is these kinds of insights from Barton that Claassens draws on and she thinks that the narrative could be used as a space for 'moral reflection'. She argues that the 'reader's emotional response to the story (and more specifically her capacity to empathize) is ethically significant' (Claassens 2012:673). In this sense Genesis 38 becomes a 'conversation starter' which creates a space where readers can enter the world of the narrative regardless of its moral complexities. But what is the point of starting a conversation if you are not sure where it will end? For Claassens it seems that the point is for readers to compare their own realities/contexts with that of the text. She looks at the narrative as part of a patriarchal structure that speaks to situations of injustice. Moreover, the narratives of Ruth and Tamar are seen as tragic circumstances where women take their future into their own hands. Both women claim their worth within their communities by resisting forces that try to eradicate their human dignity.

Returning to the Barton's argument: in his latest book (2014:171), mentioned at the beginning of the article, he argues that Old Testament narratives, despite the fact that they are difficult to reduce to 'a moral', do have some potential and in this quote Barton seems to be singing a slightly more positive tune than before:

While this might suggest to some that the narratives, too, are alien from anything like a virtue ethics, I would argue the opposite case. What we have in these stories is exactly that presentation of human beings in all their complex singularity that has been the subject of several virtue ethicists, among whom I would specially, once again, draw attention to Martha Nussbaum.

Barton still thinks that Martha Nussbaum's contribution could be helpful. He continues about the potential of ancient narratives (Barton 2014:171): 
They invite the audience to see the moral difficulties, and especially the interplay of moral choice with luck or divinely engineered fate that makes human life the complicated thing it is.

In his earlier work Barton (2003:10) put it as follows:

My suggestion is that the latter kind of narrative, at least, was conceived as a vehicle for presenting insights into the moral life of human subjects in such a way that the reader would be challenged and stimulated to thought and action.

When he mentions 'the latter kind of narrative' he is referring to narratives from Genesis and Samuel. It should be clear that the story of Tamar and Judah in Genesis 38 has all the elements mentioned by Barton. The moral difficulties faced by both Tamar and Judah seem clear to the biblical critic, although the cultural customs in the text have to be explained to the modern-day reader in order to see the complexities for what they are. A good example of such complexity would be the case of the levirate marriage, to which we will return later. Yet one wonders what exactly the audience, whether ancient or modern, is invited to see in Genesis 38? Is it really about moral choices? Or divine providence? Or both? What kind of actions or thoughts are they stimulated to engage with? Claassens's (2012:671-672) concept of 'space for moral reflection' mentioned above is actually a response to the previous quote from Barton and it seems that both are on the same page, more or less. For Claassens, in the case of Judah and Tamar in the broader context of the Joseph narrative, 'action' means that the reader is invited to follow the example of Judah and take care of the vulnerable in society, or this is how we understand Claassens at least. Yet Claassens acknowledges that Judah is 'gaining public credit' from the actions of Tamar. Judah does not do much apart from impregnating Tamar without actually knowing that he is doing it, and his character development leading him to take care of vulnerable people comes only much later in the Joseph narrative when Benjamin is in danger. Still, for Claassens the reader needs to imitate Judah in his moral growth.

In the light of this, we wonder whether Barton's statement above that 'the Hebrew Bible does not operate with any idea that one can grow in virtue' is not an over-generalisation and is probably not true of Judah in Genesis 38 and the wider Joseph narrative. To consider the purpose of ethical analysis 
and examination is to comprehend moral encounters in terms of their having the capacity to develop one and lead to future usefulness (Ogletree 2003:1). If the Old Testament is to be useful in Christian ethics, interpreters have to find ways to relate to the narratives of the people portrayed in the stories in order for them to influence the contemporary world - and this is what Claassens thinks could happen. Therefore we adopt the same approach as Barton and Claassens in terms of considering the narrative as a moral reflection on the complications of life.

Furthermore, Christians turn to biblical texts when they have moral concerns because they consider the Bible an authority on such matters (Ogletree 2003:1-2). For Christians, biblical texts relate to their own existence in that the Bible defines them as free and responsible for their own ethical development. As we engage critically with texts in terms of morality, the aim is to gain a better understanding of our own beliefs and convictions (Ogletree 2003:3). A favourable means to deal with ethics in a narrative in the Old Testament is through the concept of community (Birch 1991:25). As pointed out above, ethics in narrative are significant because they identify traits that are related to the overall meaning of a person's everyday life and relationships. Hence we approach the narrative in a similar way looking for meaning in everyday life.

In such an approach we are informed about the context of the text and its significance as a source of moral authority. Every text is part of a particular social context and ethics cannot be extracted and excluded from this setting. The people of Israel gave theological preference to the revelation of the will of God as the key factor in morality. Community in this article refers to the social group of which Judah and Tamar formed part. Although Genesis 38 was probably not written to promote moral formation, biblical criticism has developed various tools that could be valuable in explaining events when we study the story for the sake its ethical implications (Barton 1996:1-2). Essential concepts in the text such as family, marriage and levirate law first need to be clarified for the sake of contextual clarity.

\section{Community and family in Genesis 38}

Genesis 38 portrays a community where customs and family are important. As a patriarch, Judah has to ensure that the customs are upheld within 
the family. The customary practices would serve to preserve the name of the first son of Judah, Er, within the community (Davies 1981b:257-258). After the death of Er, the responsibility for preserving his name shifts to Onan, but he refused to fulfil this duty by spilling his semen on the ground. Genesis 38:9 clearly says that he was not willing to give his seed

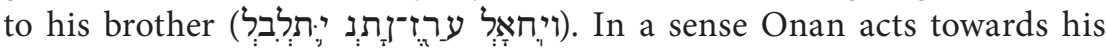
dead brother in a similar fashion as the brothers (Judah included) treated Joseph in the previous chapter. This verse reminds us that the larger story is a story about brothers who do not act as such and later Onan follows the bad example of his uncles. God sees him as wicked and puts him to death (Gen 38:8-10). The story is not unsympathetic to Judah. Verse 11 says that

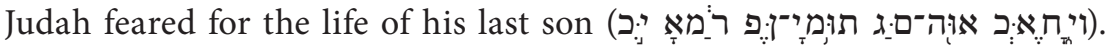
Judah is looking out for his descendants, a concern which apparently also drives Tamar and thus instead of instructing his last son Shelah to fulfil the duty, Judah sends Tamar back to the house of her father (v. 12). These circumstances and events lead Tamar into trickery. She deceives Judah by pretending to be a prostitute (vv. 15-18). Judah sleeps with her and she becomes pregnant with twins. It is fascinating to see how the birth of these twins coincides with rivalry similar to that between Jacob and Esau (Gen 25:24-26) (Ebach 2007:152-153). It seems that in Abraham's family brothers compete and brothers treat each other badly. Recently Martella (2015) has shown how sibling rivalry plays an important role in many narratives in Genesis, from Cain and Able, to Jacob and Esau, and now also in the wider Joseph narrative. We could add that chapter 38 is no exception. Onan has no loyalty to Er, and Perez and Zerah come out struggling.

In order to understand chapter 38 one also needs to know something about marriage in the Old Testament. Marriage is a key concept in the Old Testament, but it was not a 'private amorous affair' (Deist 2000:240). In principle, the marital union helped with social connections, reinforced control over property and ensured economic growth for the families involved (Matthews 2005:520-521). Not only were a man and a woman joined together, but so were their two households (Gravett et al 2008:9596). It seems that one important function was to perpetuate the family line (Deist 2000:240), or the descendants whose existence both Judah and Tamar feared for. The marital union functioned as the divine criterion that every member of the family had to measure up to (Gerstenberger 
2002:30-31). If a man therefore died childless, his brother (or any close relative) had the responsibility to provide his widow with a child (Alter 1996:217-223). The term 'levirate marriage' has its origin from the Latin levir, which refers to a brother-in-law (Gravett et al 2008:95-96). A full description of the custom is found in Deuteronomy 25:5-10. The custom of levirate marriage is found in many cultures in the Ancient Near East (Davidson 1979:226-230). There are three references to the custom in the Bible, namely in Genesis 38, Deuteronomy 25:5-10 and the story of Ruth (Davies 1981:138-139).

One purpose of the levirate was to provide the widow with offspring (Wenham 1994:366-368; Alter 1996:217-223; Frymer-Kensky 2000:161163). Another purpose was to carry on the name of the deceased husband (Davies 1981a:140-144; Deist 2000:240). The widow was provided with an heir who could carry on the name of the deceased but also give protection to her (Davidson 1979:230). The woman remained within the family and retained a heritage within the family (Roop 1987:248-254). Accordingly, the son born from the one who was fulfilling the duty became the legal child and heir of the deceased man and had a right to his property and name. The widow was given financial security. Also, having a son gave her social status, which she was deprived of because of her widowhood. She had protection within the community. Matlock (2007:295) identifies three purposes for the levirate: (1) to continue the name of the clan, (2) to inherit land, and (3) to ensure that the widow was provided for. Some men were not keen to perform this duty (Weisberg 2004:403), which is evident in that both Onan and Judah tried to avoid the issue (although for different reasons). Yet Judah had a moral obligation towards Tamar to treat her fairly in terms of custom (Davidson 1979:226-230).

Similarly, the fulfilment of levirate duty does not appear to have been obligatory, according to the narratives of Tamar and Ruth as well as the account given in Deuteronomy (Manor 1984:134-135, Wenham 1994:366367). The punishment mentioned for the one who refused to uphold the law was public disgrace for him and his family (Phillips 2002:111-126). Judah imposes the duty in Genesis 38, but in Deuteronomy 25:5-10 the brotherin-law can decide whether or not he wants to perform the duty. Although Deuteronomy acknowledges the law as customary, it cannot be imposed by the court (Phillips 2002:111-126). In the case where the brother in law 
neglected to fulfil the duty, the widow could bring him before the court, where they could try to persuade him to fulfil the duty. If he still refused to fulfil the duty, the woman could publicly humiliate him by taking one of his shoes and spitting in his face (Deut. 25:8). Yet the main problem with Onan was that he faked it. It seemed to everybody (Judah included) as if he was fulfilling his duties, but the story tells us that that was not the case. Onan turns out to be a trickster like his grandfather Jacob - a strategy which Tamar also eventually follows with great success, although the narrative seems to find the trickery of Tamar acceptable compared to that of Onan. ${ }^{5}$ Onan ends up dead and Tamar has twins and she is described as the one in the right by Judah.

\section{The promise of progeny in narrative}

Biblical ethics in the Old Testament cannot be differentiated from biblical theology (Birch 1991:24). There is a link between ethics in the Old Testament and its theological witness. Biblical scholars make it clear that the promise of progeny, which plays an important theological role, is a key feature of the patriarchal narratives and no discussion of ethics is possible without taking this into account (Davidson 1979:222-230; Wenham 1994:366; Collins 2004:100-101).

Judah in fact goes through great lengths to retain an heir, while Tamar does anything possible to obtain one. But instead of giving her his son, Judah requests that she return to the house of her father without any inheritance rights or the opportunity to remarry; he expects her to remain there until he decides otherwise (Gunn \& Fewell 1993:36-38). She obeys Judah's request and returns to her own family to wait for him to give one of his sons to her in compliance with the levirate custom. After a while she decides to take matters into her own hands and to provide her late husband with an heir. She does so by means of prostitution and risks her life in the process to protect the memory of her husband. She counted on Judah to allow one of his sons to perform the duty, but he denied her this fulfilment. One also has to consider the dilemma of Judah, who has already lost two of his own

5 For a more detailed discussion of trickery and its ethical ambiguity, see Pietersen and Fourie (2015:4-6). 
sons and may well have tried to look out for his own family by keeping his last son from her as a means of protecting his family. The story keeps Judah in the dark about why his two sons died and he might think that it has something to do with Tamar. However, being without an heir makes Tamar's future uncertain and means that her late husband's legacy will not live on in the community (Brodie 2001:351).

Besides the importance of perpetuating the community, family relationships were another essential element in this community. Gerstenberger (2002:31) posits that the family was the source not only of loyalty to the community but also of trustworthiness. Children therefore had the sacred responsibility to fit into the community and to ensure that the community flourished. The importance of family then raises awareness of right relations between members in this community (Davidson 1979:222-230). It can be argued that relationships were shaped by the traditions of the group and therefore the narrative depicts the importance of upholding tradition in order for the community to survive. Morally good behaviour in terms of relational responsibility was imperative within the family, because the family ensured identity within the community (Matthews 2005:520-530). Each family member had a duty to fulfil toward the others in terms of their relationship (Malchow 1996:16-17). Every family member was subject to the established customs, but the weaker person could make a serious request for the reversal of a decision (Gerstenberger 2002:31). This might explain the behaviour of Tamar. She does not explicitly appeal Judah's decision to send her to her father, as one finds in Deuteronomy 25, but instead reverts to trickery. The question then is why does Judah exclaim 'she is more righteous/just than I' (Gen. 38:24-26)?

At this point, it is important to note that justice was based on the way people treated each other within the family. In other words, justice referred to behaviour that conformed to cultural practices (Manor 1984:135). A person who fulfilled the conditions imposed on him or her by these relationships was seen as righteous. Hence, in this case, righteousness should be considered in a strictly legalistic sense (Birch 1991:153-154). The injustice is that Onan has no intention to perform the levirate duty but still sleeps with Tamar. Instead of being loyal to his deceased brother, he serves his own interests as he would presumably otherwise forfeit the inheritance, 
which would go to the heir whom he and Tamar conceive because the child would be considered the son of his brother Er (Davies 1981:258).

Ebach (2007:145-149) also engages with the problem of the 'righteousness' of Tamar. He asks what exactly the answer by Judah might mean and eventually defines it as follows (Ebach 2007:146):

In der Beziehung, in der Tamar zu mir stand und steht, angesichts dessen, was ich ihr in dieser Beziehung schuldig blieb, ist sie im Recht and hat gerecht gehandelte. ${ }^{6}$

Thus the righteousness of Tamar has to do with the fact that by means of trickery she helped Judah to be true to his responsibilities as her father-inlaw. Ebach (2007:147) emphasises that righteousness in the biblical text is always a relationship category (Beziehungskategorie).

It is not clear whether Tamar could also have brought him before the elders for punishment as set out in Deuteronomy 25:5-10, where it states that a widow could bring her brother-in-law or next of kin before the elders if they refused to fulfil the levirate duty. Does this apply to a father-in-law? We do not know. If it were the case, the elders would have reprimanded him even though they could not enforce the duty upon him. In such a case, the widow was allowed to publicly humiliate the man. This may have been the reason why Tamar requested the seal and cord of Judah as payment for her sexual favours, as she might have needed to expose him later, which she does in a sense, although the narrative does not paint a picture of public humiliation for Judah. It sounds more like a private humiliation which leads to the insight that she was right and he wrong. As an authority figure, Judah was expected to prevent this type of behaviour in his family. He had to ensure that Tamar was treated justly (Wildavsky 1994:37). By fulfilling his responsibility, Judah would have restored not only the name of his son but also the happiness of his family, because the group would continue to exist (Calvin 1975:295-300). It seems that Tamar is the only one who fulfils the demands of the relationship, because Judah deprives her of her right (Malchow 1996:16-17).

6 We would translate this roughly as follows: With regard to the relationship that Tamar has and had with me and my obligation towards her, she is right and she acted correctly. 


\section{Christian ethics and narrative}

The interpreter or reader has to keep the context of the narrative in mind in attempting to find ethical meaning in the text. Rogerson (2001:29) argues that although biblical texts can guide the believer in his or her daily life, the Old Testament contains material that is often displeasing to modern readers. Also, the behavioural traits of some of the characters are not only unlawful but also distasteful to contemporary readers (Rogerson 2001:29). The example in our story of Judah declaring that Tamar is more righteous than he after she had tricked him into sleeping with her would be a good example of what is distasteful to the modern reader. For this reason it may be difficult to find a link between Christian ethics and Old Testament ethics. In considering Christian ethics, the behaviour of both Judah and Tamar may seem scandalous (Rogerson 2001:29). However, if the narrative is linked to biblical tradition (Roop 1987:248), then Tamar is in line with the cultural practice (Wildavsky 1994:37). Judah is not, although the stories seem to show that the experience changes him. Tamar eventually plays a role in the fulfilment of the promises of descendants made to the patriarchs in the book of Genesis. She is instrumental in the fulfilment of these promise and she is written into the genealogy of David.

Claassens (2012:668) makes another interesting point when she discusses the notion of 'seeing the face of the other'. She argues) that to be human it is important to regard the inherent human need to be seen or recognised. Here the term 'need' is understood 'as the desire to be treated as a subject whose voice is heard and whose needs are recognized.'

Judah and his sons had a responsibility toward Tamar. Not fulfilling this responsibility had serious repercussions for the community. Nevertheless, Judah still refused to adhere to custom. It also seems as if the author sympathises more with Tamar in her situation than with Judah, who has already lost two sons. Regardless of the prostitution, the reader sees Tamar as a widow claiming or fighting for her right. Eventually Judah identifies this by acknowledging that Tamar is the righteous one; consequently, her righteous act 'inspires him to act in greater righteousness than he has previously shown' (Claassens 2012:670). Tamar makes him see her and he does eventually. 
If the narrative is considered as a conversation starter, what conversation are we referring to in this instance? It should be clear from the discussion up to now that the story forces us to talk about community and interpersonal relationships. Yet a community is also formed by the narratives that are told in different periods of time (as is the case with biblical texts). Like the community in Genesis 38, Christians today are considered the people of God. Therefore, the community establishes how the plot and characters of a narrative will influence their own characters (Cunningham 2008:6667). Narratives and customs are evident in a shared outlook and behaviour, which can then also sustain the community through history and tradition. Likewise, the narratives people tell and are told depend on the community that they are part of (Cunningham 2008:39). The use of biblical material is controlled by the foundation on which the community is build. The moral life of a person is not isolated from that of his or her community. From the events that unfold in Genesis 38 it is clear that this also applies to Tamar and Judah. Hence, if people become separated from their community, they would struggle to recognise who or what they are (Hauerwas 1981:9-15). As a conversation starter, Genesis 38 creates a means of association linking the lives of people, creating a community, in a sense.

Being moral means that one has to attain intrinsic worth, which gives one the ability to determine what, is ethically right. It is only by participating in communal life that a person acquires this orientation. The community is nourished and shaped in creating people who can effectively live out its story. It is important for community ethics to find a means to explain the different ways of sustaining human relationships without suppressing or altering the differences between the people within the group (Kirkpatrick 2001:1-10). One has to consider that Judah and Tamar formed part of a particular society; their behaviour should be considered as being informed by their social setting. The narrative does not draw the attention of the interpreter to the situation but rather to the kind of person Tamar ought to be in the situation as part of a particular society (Hauerwas 1981:9-15). For the most part, the narrative addresses right relations between members of the society (Phillips 2002:201-210). 
This, in turn, confirms that the levirate custom served to ensure the prosperity of the group in that the deceased husband continued to live through offspring (Wenham 1994:366-368). But the welfare of the widow was also ensured within the community. It is clear that the behaviour of Tamar is in line with the recognised custom, irrespective of how bad the interpreter may regard her actions to be. In her own society she is portrayed as a loyal wife and family member. She is committed to her family and her trickery produces descendants and fulfilment of the promises of God to the patriarchs. The story is indeed, as Barton (2014:171) said about 'the interplay of moral choice with luck or divinely engineered fate.'

\section{Conclusion}

In this article we have discussed the difficulty of using a text in the Old Testament for the purposes of ethical reflection. Barton called Old Testament stories 'reticent,' but this is clearly not applicable to this story. It truly invites the hearer to participate in a discussion, as Claassens argued. It also seems that Barton is wrong about the fact that there is usually very little moral development in the characters in Old Testament narratives. As both Claassens and Wünch showed, Judah is a changed man, but this conclusion can only be drawn when his narrative is read within the wider Joseph narrative.

Although most biblical scholars do not focus on ethics, their approaches to Old Testament texts are still more than useful to stimulate ethical discussion. In the article we pointed out that biblical scholars consider narratives as ways to start conversations about the complexities of life. In this sense narratives can serve as a platform to reflect on the 'bigger picture' when faced with a moral dilemma in pointing out that life is not simple. Consequently, our moral decisions are not based on a clear set of rules and regulations. The ultimate value which this story seems to propagate is that family comes first. This is a powerful message within the wider literary context of brothers treating each other badly. Tamar helps Judah to break this cycle, getting him to take care of the vulnerable, as Claassens put it. 


\section{Bibliography}

Abasili, AI 2011a. 'Genesis 38: The Search for Progeny and Heir.' SJOT $25: 2,276-288$.

Abasili, AI 2011b. 'Seeing Tamar through the Prism of an African

Woman: A Contextual Reading of Genesis 38.' OTE 24:3, 555-573.

Alt, A 1989. Essays on Old Testament History and Religion. Sheffield: JSOT Press.

Alter, R 1996. Genesis: Translation and Commentary. New York: Norton \& Company.

Amit, Y 2009. 'Narrative Analysis: Meaning, Context, and Origins of Genesis 38.' in JM LeMon and KH Richards (eds.) Method Matters: Essays on the Interpretation of the Hebrew Bible in Honor of David L. Petersen. Atlanta: SBL, 271-291. (Resources for Biblical Study 56)

Barton, J 1996. Reading the Old Testament: Method in Biblical Study. Louisville: Westminster John Knox Press.

Barton, J 2002. Ethics and the Old Testament. Second Edition. London: SCM Press.

Barton, J 2003. Understanding Old Testament Ethics: Approaches and Explorations. Louisville: Westminster John Knox Press.

Barton, J 2014. Ethics in Ancient Israel. Oxford: Oxford University Press. Birch, BC 1991. Let Justice Roll Down: The Old Testament, Ethics, and Christian Life. Louisville: Westminster John Knox Press

Brodie, TL 2001. Genesis as Dialogue: A Literary, Historical and Theological Commentary. New York: Oxford University Press.

Calvin, J 1975. Genesis (Two Volumes in One). Carlisle: The Banner of Truth Trust.

Carr, DM 2005. Writing on the Tablet of the Heart: Origins of Scripture and Literature. Oxford University Press, New York.

Claassens, LJM 2012. 'Resisting Dehumanization: Ruth, Tamar, and the Quest for Human Dignity.' Catholic Biblical Quarterly 74, 659-674. 
Collins JJ 2004. Introduction to the Hebrew Bible. Minneapolis: Fortress Press.

Cunningham, DS 2008. Christian Ethics: The End of the Law. London: Routledge.

Davies, EW 1981a. 'Inheritance Rights and the Hebrew Levirate Marriage Part 1.' Vetus Testamentum 31:2, 138-144.

Davies, EW 1981b. 'Inheritance Rights and the Hebrew Levirate Marriage, Part 2.' Vetus Testamentum 31:3, 257-268.

Davidson, R 1979. Genesis 12-50. London: Cambridge University Press.

Deist, FE 2000. The material culture of the Bible: An Introduction. Sheffield: Sheffield Academic Press.

Ebach, J 2007. Genesis 37-50. Freiburg: Herder. (HTKAT)

Fowl, S 2006. 'The Ethics of Interpretation or What's Left Over After the Elimination of Meaning.' in SJA Clines, S Fowl \& SE Potter (eds.) The Bible in Three Dimensions: Essays in Celebration of Forty Years of Biblical Studies in the University of Sheffield. Sheffield: JSOT Press, 379-397.

Fowl, SE \& Jones, LG 1991. Reading in Communion: Scripture and Ethics in Christian Life. Grand Rapids: William B. Eerdmans.

Frymer-Kensky, T 2000. 'Tamar 1.' in C Meyers (ed.) Women in Scripture: A Dictionary of Named and Unnamed Women in the Hebrew Bible, the Apocryphal/ Deuterocanonical Books, and the New Testament. Grand Rapids: Eerdmans, 161-163.

Gerstenberger, ES 2002. Theologies in the Old Testament. London: T\&T Clark.

Goldingay, J 1987. Theological Diversity and the Authority of the Old Testament. Grand Rapids: Eerdmans.

Gravett, SL, Bohmbach, KG, Greifenhagen, FV \& Polaski, DC 2008. An Introduction to the Hebrew Bible: A Thematic Approach. Louisville: Westminster John Knox Press. 
Gunn, DM \& Fewell, DN 1993. Narrative in the Hebrew Bible. New York: Oxford University Press.

Hauerwas, S 1981. A Community of Character: Toward a Constructive Christian Social Ethic. Notre Dame: University of Notre Dame Press.

Kim, D 2012. 'The Structure of Genesis 38: A Thematic Reading.' Vetus Testamentum 62, 550-560.

Kruschwitz, J 2012. 'The Type-Scene Connection between Genesis 38 and the Joseph Story.' JSOT 36:4, 383-410.

Leuchter, M 2013. 'Genesis 38 in Social and Historical Perspective.' JBL 132:2, 209-227.

Malchow, BV 1996. Social Justice in the Hebrew Bible: What is New and What is Old? Collegeville: Liturgical Press.

Manor, DW 1984. 'A Brief History of Levirate Marriage as it Relates to the Bible.' Restoration Quarterly 27:3, 129-142.

Martella, MI 2015. Geschwisterrivalitäten im Buch Genesis: Eine literaturwissenschaftliche Analyse augewählter Geschwisterrivalitäten. Unpublished MTh Dissertation, University of South Africa.

Matlock, MD 2007. 'Obeying the First Part of the Tenth Commandment: Applications from the Levirate Marriage Law.' Journal for the Study of the Old Testament 31:3, 295-310.

Matthews, VH 2005. 'Israel Society.' in BT Arnold \& HGM Williamson (eds.), Dictionary of the Old Testament Historical Books: A Compendium of Contemporary Biblical Scholarship. Nottingham: InterVarsity Press, 520-530.

Mills, ME 2001. Biblical Morality: Moral Perspectives in Old Testament Narratives. Hampshire: Ashgate.

Montague, GT 2007. Understanding the Bible: A Basic Introduction to Biblical Interpretation. New York: Paulist Press.

Ogletree, TW 2003. The Use of the Bible in Christian Ethics. Louisville: Westminster John Knox Press. 
Phillips, A 2002. Essays on Biblical Law. New York: Sheffield Academic Press.

Pietersen, L \& Fourie, W 2015. 'The Bible, culture and ethics: Trickery in the narrative of Judah and Tamar.' HTS Teologiese Studies/Theological Studies 71:3, Art. \#2937, 8 pages.

Rogerson, JW 2001. 'The Old Testament and Christian Ethics.' in R Gill (ed.) The Cambridge Companion to Christian Ethics. Cambridge: Cambridge University Press, 29-41.

Roop, EF 1987. Genesis: Believers Church Bible Commentary. Ontario: Herald Press.

Weisberg, DE 2004. 'The Widow of Our Discontent: Levirate Marriage in the Bible and Ancient Israel.' Journal for the Study of the Old Testament 28:4, 403-429.

Wenham, GJ 1994. Genesis 16-50. Volume 2. Dallas Word Books. (Word Biblical Commentary)

Wenham, GJ 2000. Story as Torah: Reading the Old Testament Ethically. Edinburg: T\&T Clark.

Wildavsky, A 1994. Survival Must Not be Gained Through Sin: the Moral of the Joseph Stories Prefigured through Judah and Tamar on 14 June 1999. Journal for the Study of the Old Testament 62, 37-48.

Wünch, H-G 2012. 'Genesis 38 - Judah’s Turning Point: Structural Analysis and Narrative Techniques and their Meaning for Genesis 38 and its Placement in the Story of Joseph.' OTE 25:3, 777-806. 